\title{
Rapid changes in stocks of ciliate microzooplankton associated with a hurricane in the Bohai Sea (China)
}

\author{
Wuchang Zhang*, Rong Wang \\ Marine Ecology Department, Institute of Oceanology, Chinese Academy of Sciences, 7 Nanhai Road, Qingdao 266071, PR China
}

\begin{abstract}
The ciliate community in the Bohai Sea (China) was studied from 23 September to 7 October 1998. A hurricane struck the study area between the 2 grid station investigations, which were $6 \mathrm{~d}$ apart. The ciliate biomass decreased drastically after the hurricane. The surface ciliate biomass decreased from $0.2-12.3$ to $0.02-2.8 \mu \mathrm{g} \mathrm{C} \mathrm{l}^{-1}$ and the water column ciliate biomass from $2-136$ to $0.01-47 \mathrm{mg} \mathrm{C} \mathrm{m}^{-2}$. The ciliate biomass:chlorophyll ratios in the surface water were calculated to be 0.04 to 4.7 (1.41 on average) during the first grid investigation and 0.01 to 1.18 (0.26 on average) during the second grid investigation. Distinct patterns of temporal changes in ciliate abundances were found at different stations both before and after the hurricane.
\end{abstract}

KEY WORDS: Ciliate $\cdot$ Biomass $\cdot$ Microzooplankton $\cdot$ Bohai Sea

Resale or republication not permitted without written consent of the publisher

Ciliates are one of the main components of microzooplankton. The abundance and biomass of ciliates have been widely reported (e.g. Perez et al. 1997, 2000). Many studies about the seasonal variation of ciliate abundance have been reported. In these investigations, samples were usually taken monthly (Wasik \& Mikolajczyk 1994), biweekly (Pierce \& Turner 1994, Kamiyama \& Tsujino 1996) or weekly (Barria de Cao 1992). However, ciliate community generation times are a few days or less (Dolan 1991, Perez et al. 1997) and strongly influenced by environmental factors (Kamiyama \& Tsujino 1996). Data available from shortinterval sampling programs are currently very limited (Kamiyama 1995, Perez et al. 2000).

Until recently, little information on ciliate stocks in the China Seas could be found (Hu et al. 1999). In the present study, we report on the rapid changes in stocks of ciliate microzooplankton associated with a hurri-

*E-mail: w.c.zhang@usa.net cane in the Bohai Sea (China). At the anchor stations (Stns E3, B1 and A4) and the drift station, 3 or $4 \mathrm{~h}$ interval variations of ciliate abundance were estimated.

Materials and methods. The Bohai Sea is a mid-latitude temperate semi-closed inland sea with an average depth of $18 \mathrm{~m}$. The Huanghe River and several other rivers discharge into the Bohai Sea. The ciliate community in the Bohai Sea was studied from 23 September to 7 October 1998 on board the RV 'Dongfanghong No. 2'. There were 30 stations (Fig. 1) altogether, with the minimum depth at Stn D1 (14.4 m) and the maximum depth at Stn A4 $(52 \mathrm{~m})$. The investigation process was divided into several stages as shown in Table 1.

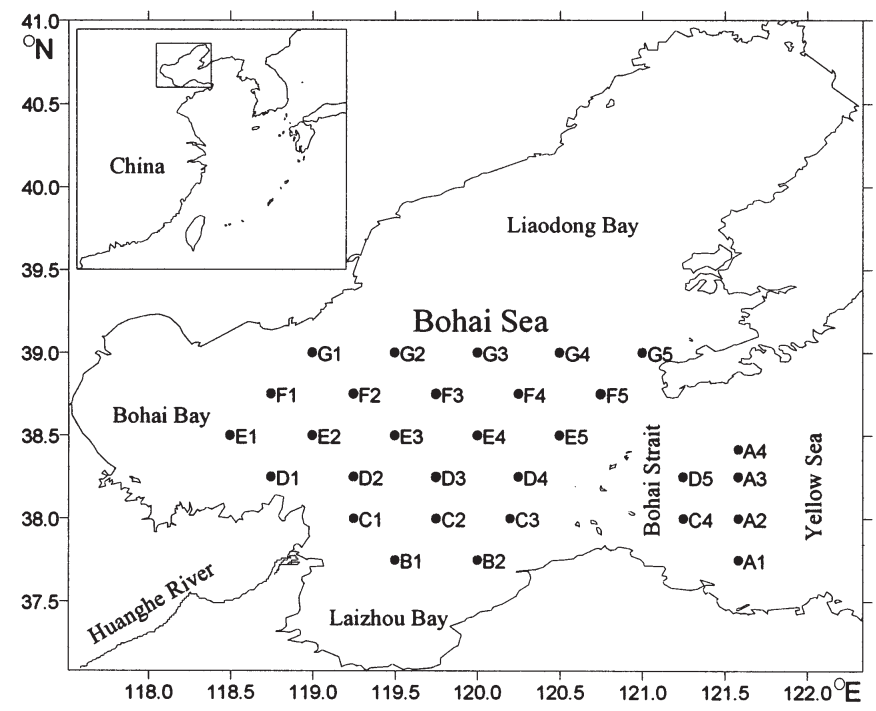

Fig. 1. Map of the study site in the Bohai Sea (China). Experiments were conducted from 23 September to 7 October 1998 at 30 stations 
Table 1. The Bohai Sea investigation process

\begin{tabular}{|c|c|}
\hline Time & Investigation items \\
\hline 24-27, Sep & $\begin{array}{l}\text { The first grid station investigation: Stns A1-A4-G5-G1-F1-F5-E5-E1-D1-D4-C3- } \\
\text { C1-B1-B2-D5-C4 }\end{array}$ \\
\hline 08:00 h, 29 Sep-05:00 h, 30 Sep & Anchor Stn E3, sampling every $3 \mathrm{~h}$ \\
\hline 08:00 h, 30 Sep-05:00 h, 1 Oct & $\begin{array}{l}\text { Drift Stn E3, a buoy was released to the sea. The ship followed the buoy in order to } \\
\text { sample the same water mass. The buoy drifted less than } 8 \text { sea miles. Sampling every } 3 \mathrm{~h}\end{array}$ \\
\hline 05:00 h, 1 Oct $-01: 00$ h, 2 Oct & Drift Stn E3, sampling every $4 \mathrm{~h}$ \\
\hline 01:00 h-22:00 h, 2 Oct & $\begin{array}{l}\text { Hurricane struck, the ship sailed to Anchor Stn B1 and anchored due to bad weather } \\
\text { conditions }\end{array}$ \\
\hline $22: 00$ h, 2 Oct $-10: 00$ h, 3 Oct & Anchor Stn B1, sampling every $3 \mathrm{~h}$ \\
\hline $10: 00$ h, 3 Oct $-12: 00$ h, 6 Oct & $\begin{array}{l}\text { The second grid station investigation: Stns B1-B2-C1-C3-D4-D1-E1-E5-F5-F1- } \\
\text { G1- G5-D5-C4-A1-A4 }\end{array}$ \\
\hline $12: 00$ h, 6 Oct $-00: 00$ h, 7 Oct & Anchor Stn A4, sampling every $3 \mathrm{~h}$ \\
\hline
\end{tabular}

First grid investigation

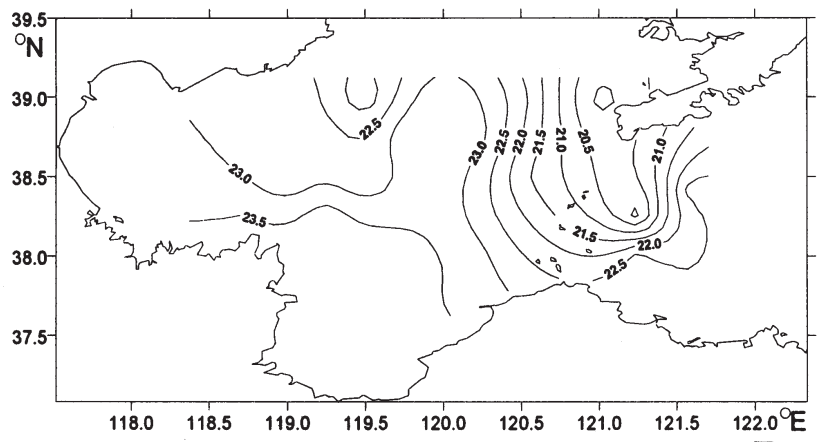

Second grid investigation

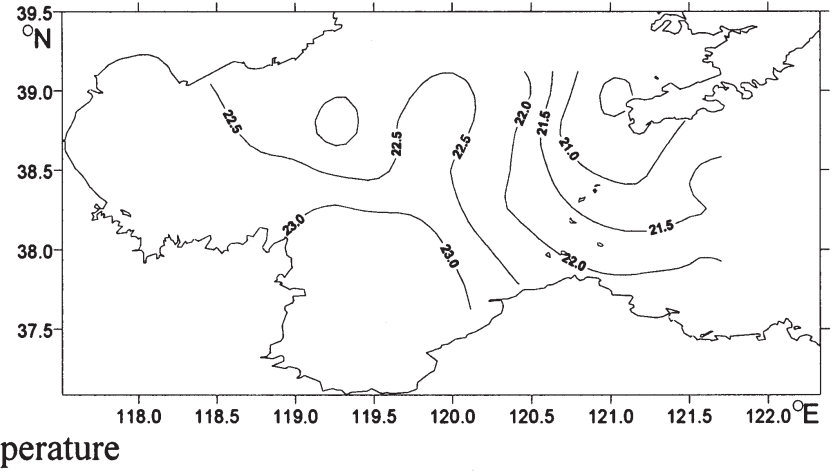

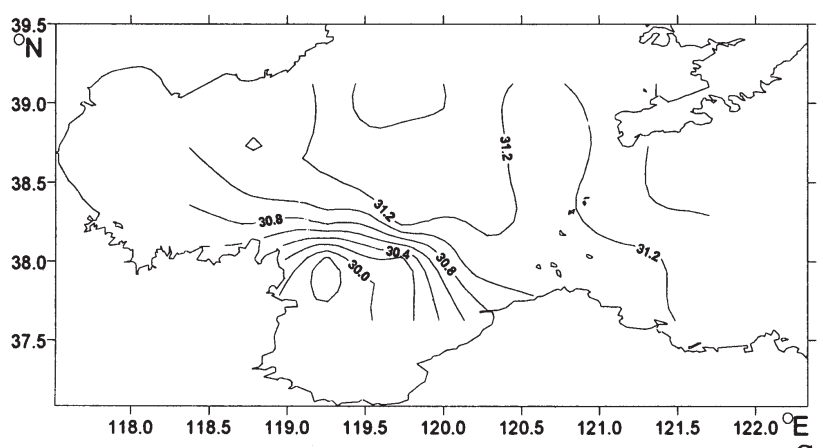
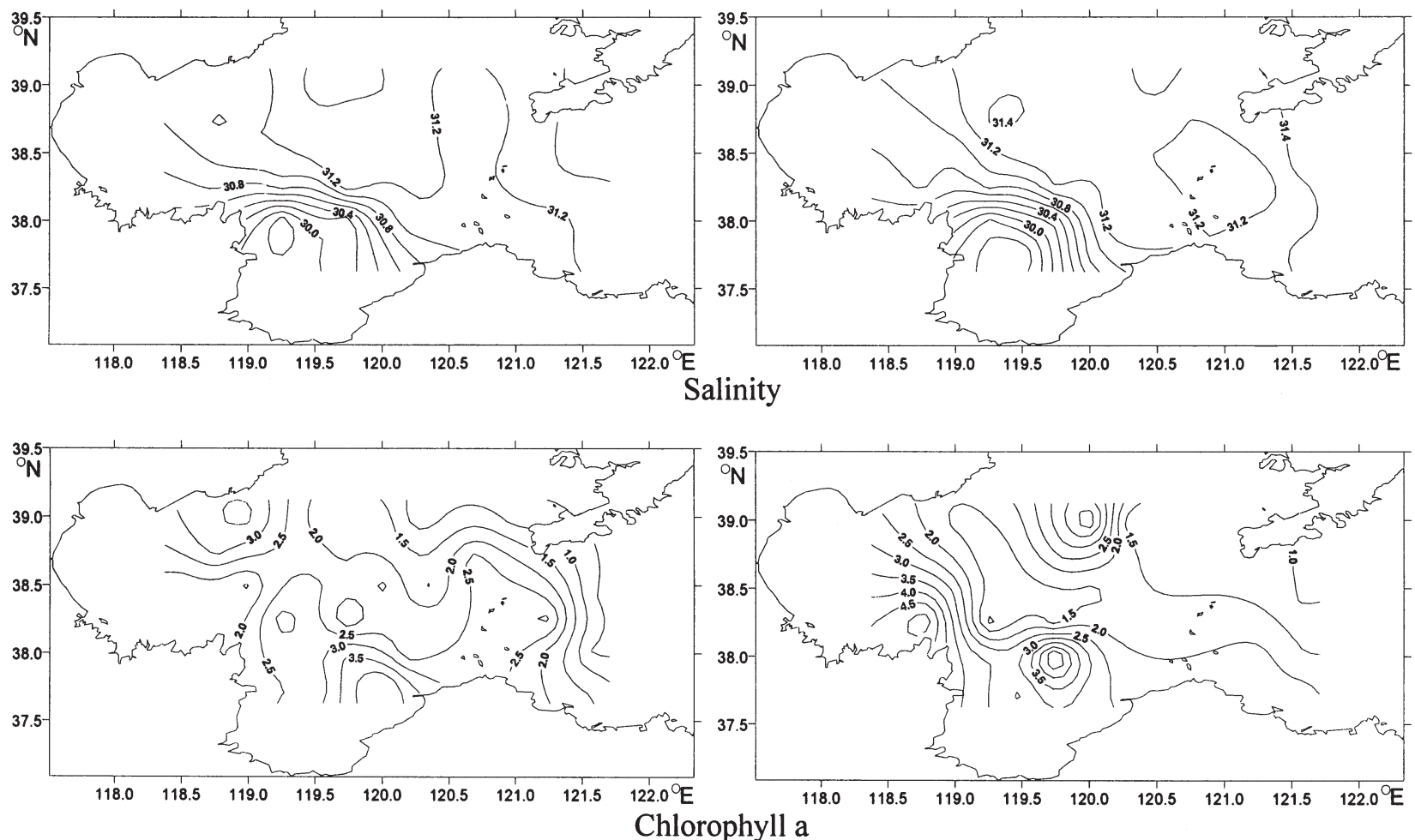

Fig. 2. Surface temperature $\left({ }^{\circ} \mathrm{C}\right)$, salinity and chlorophyll a concentration $\left(\mu \mathrm{g} \mathrm{l}^{-1}\right)$ during the 2 grid station investigations 
First grid investigation

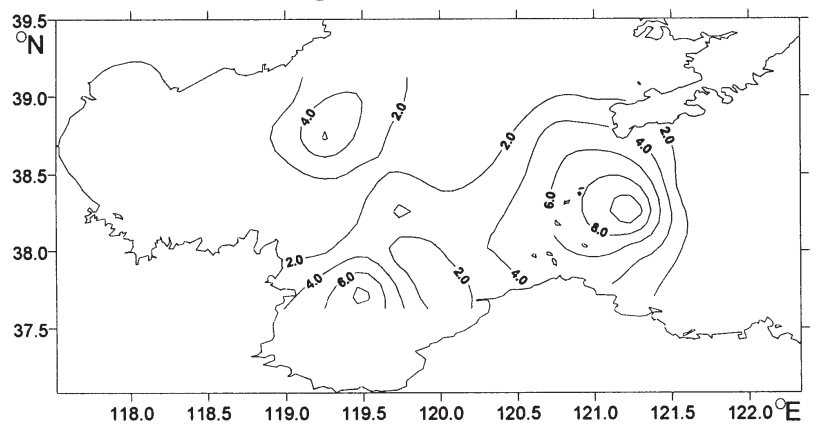

Surface biomass

\section{Second grid investigation}

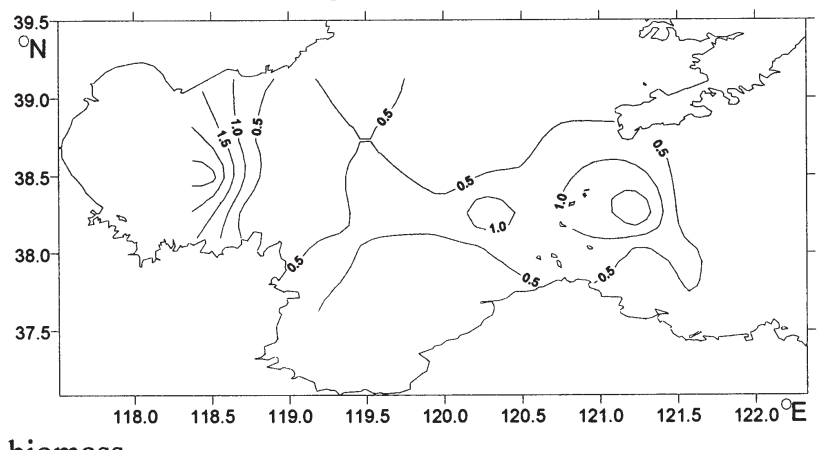

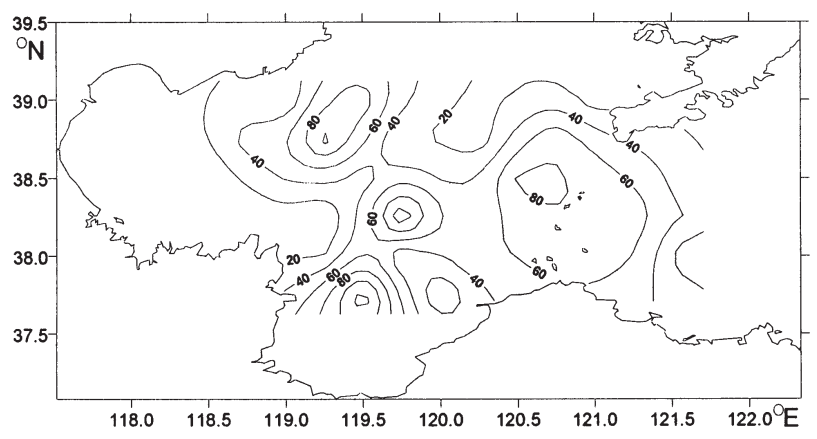

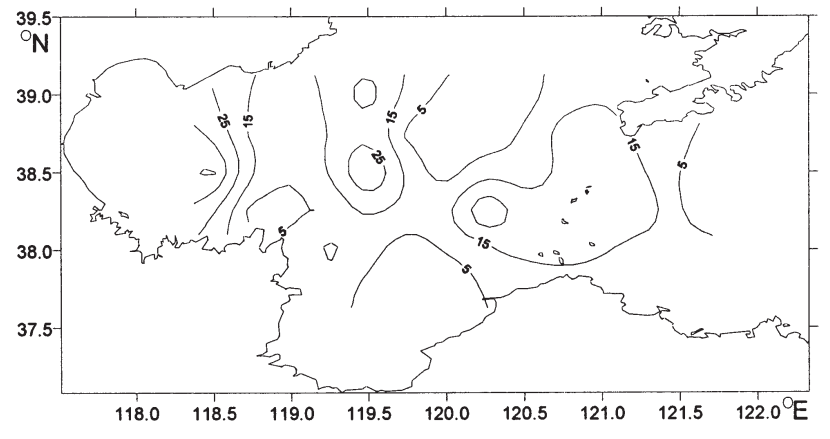

Column biomass

Fig. 3. Surface biomass $\left(\mu \mathrm{C} \mathrm{Cl}^{-1}\right)$ and column biomass $\left(\mathrm{mg} \mathrm{C} \mathrm{m}^{-2}\right)$ during the 2 grid station investigations

Water samples were collected using 2 liter Rossette sample bottles from the surface, 5 and $10 \mathrm{~m}$ depths and the bottom ( $5 \mathrm{~m}$ above the bottom). The temperature and salinity profiles were measured using a SeaBird CTD. Chlorophyll concentration was determined with the spectrophotometric measurements according to Strickland \& Parsons (1972), with the substitution of the equations of Jeffrey \& Humphrey (1975).

A 11 water sample from each depth was preserved with $2 \%$ acid Lugol's iodine solution in plastic bottles. The samples were counted using an Axiovert microscope at $150 \times$ magnification after pre-concentration by serial settling methods. The cell concentrations are considered to be minimum estimates because only ciliates with a maximum preserved dimension of $>20 \mu \mathrm{m}$ were counted.

The dimensions of the ciliates were measured using an Olympus microscope at 200 or $400 \times$ magnification. The average dimensions were derived from measurements of at least 30 animals for each species; fewer individuals were used in the case of rare taxa. The cell volume of each species was estimated using appropriate geometric shapes (balls, cones, cylinders and their combinations). The total plasma volume of tintinnids is assumed to occupy $30 \%$ of the lorica volume (Gilron \& Lynn 1989). The carbon:volume ratio used to calculate biomass of ciliates was $0.19 \mathrm{pg} \mathrm{C} \mathrm{m}^{-3}$ (Putt \& Stoecker 1989).

Results. The surface temperature, salinity and chlorophyll concentrations during the 2 grid station investigations are shown in Fig. 2.

During the first grid station investigation (24 to 27 September 1998), the ciliate biomass on the surface was 0.2 to $12.3 \mathrm{mg} \mathrm{Cl}^{-1}$, with peaks appearing at Stns $\mathrm{B} 1, \mathrm{D} 5$ and F2 (9.1, 12.3 and $6.6 \mu \mathrm{g} \mathrm{C}^{-1}$ respectively). The water column biomass was 2 to $136 \mathrm{mg} \mathrm{C} \mathrm{m}^{-2}$. The spatial pattern of water column biomass resembles that of the surface biomass. Because only 4 depths were sampled, some details could be missed in the condition of deep waters. Therefore, the water column biomasses at the deep stations are rough estimates.

The second grid station investigation (3 to 6 October 1998) yielded lower estimates of ciliate biomass. The surface layer biomass ranged between 0.02 and $2.8 \mathrm{mg}$ $\mathrm{C}^{-1}$, with the maximum at Stn E1. Water column biomass ranged between 0.01 and $47 \mathrm{mg} \mathrm{C} \mathrm{m}^{-2}$ (Fig. 3).

The ciliate biomass:chlorophyll ratios in the surface water were calculated to be 0.04 to 4.7 (1.41 on average) during the first grid investigation and 0.01 to 1.18 ( 0.26 on average) during the second grid investigation.

The time series sampling revealed distinct differences between stations both prior to and after the hur- 

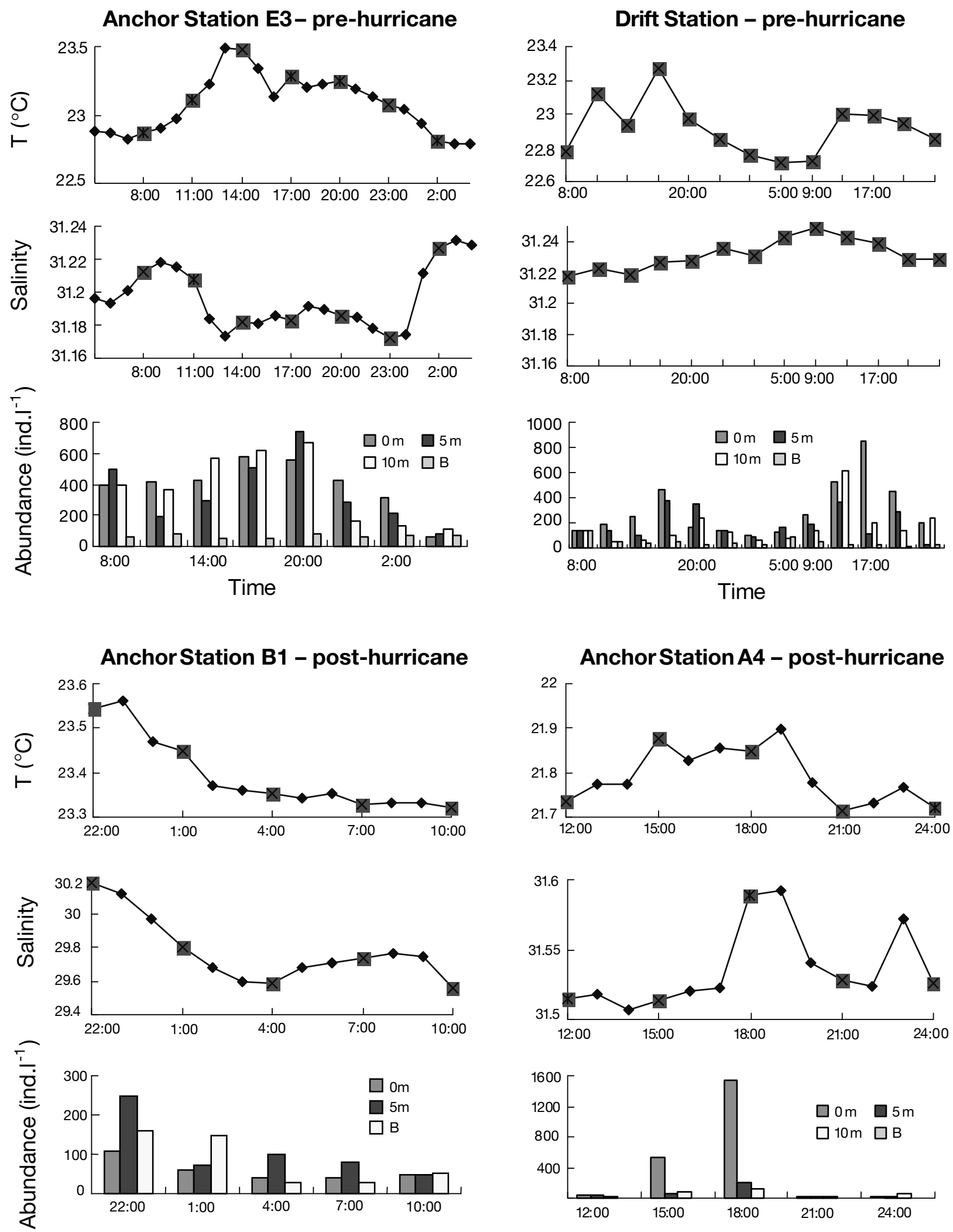

Time

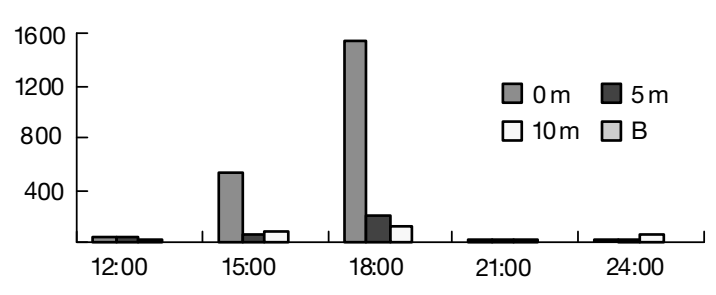

Time

Fig. 4. Dynamics of temperature, salinity and total ciliate abundance at anchor stations (Stns E3, B1 and A4) and the drift station. Boxes $(\square)$ in the temperature and salinity panels show the times when the ciliate samples were taken 
ricane (Fig. 4). The Anchor Stn E3 and the drift station, both occupied before the hurricane, showed distinct temporal peaks in ciliate concentrations. Abundances at Stn E3 were maximal around 20:00 h while at the drift station peak concentrations were recorded from samples taken at about 17:00 h. For both time series, ciliate concentrations did not appear to co-vary with temperature or salinity. Interestingly, the 2 time series conducted after the hurricane at Anchor Stns B1 and A4 also showed distinct temporal patterns of ciliate abundance. Data for Anchor Stn B1 showed a regular decline in ciliate number from 22:00 to 10:00 h. In contrast, ciliate concentrations peaked distinctly at Anchor Stn A4 at about 18:00 h. Thus, both before and after the hurricane, different stations showed different patterns of ciliate abundance.

Discussion. In western Hiroshima Bay, the Seto Inland Sea (Japan), the temporal change in the microzooplankton community during the decay of a bloom of Heterosigma akashiwo was recorded over a $10 \mathrm{~d}$ period in June-July 1991 (Kamiyama 1995). The ciliate density increased rapidly when the density of $H$. akashiwo decreased drastically due to the vertical mixing. This process lasted only $4 \mathrm{~d}$. Both the results of Kamiyama (1995) and this study suggest that physical processes such as vertical mixing by storms could influence the ciliate community drastically. The possibility of irregular patterns of temporal variability independent of water mass changes further complicates interpretations (e.g. Perez et al. 2000).

In this paper, the fluctuation of the ciliate abundance at the anchor stations (Stns E3, B1 and A4) and the drift station may be interpreted as the change of the watermass. The variations of temperature and salinity justified this causation. Although the high ciliate concentrations coincided with the high temperatures at those stations, temperature may not be the definitive factor that controls the occurrence of ciliates. As pointed out by Sanders (1987) and Kamiyama \& Tsujino (1996), correlation must not necessarily mean causation.

Acknowledgements. This study was supported through the National Science Foundation of China Grant No. 49790010. We are grateful to the crew of RV 'Dongfanghong No. 2' for their time and cooperation. Hongyan Zhang provided the

Editorial responsibility: John Dolan, Villefranche-sur-Mer, France map of the Bohai Sea. Two anonymous referees offered valuable advice and suggestions on an earlier draft of this manuscript.

\section{LITERATURE CITED}

Barria de Cao MS (1992) Abundance and species composition of Tintinnina (Ciliophora) in Bahia Blanca Estuary, Argentina. Estuar Coast Shelf Sci 34:295-303

Dolan JR (1991) Microphagous ciliates in mesohaline Chesapeake Bay waters: estimates of growth rates and consumption by copepods. Mar Biol 111:303-309

Gilron GL, Lynn DH (1989) Estimates of in situ population growth rates of four Tintinnine ciliate species near Kingston Harbour, Jamaica. Estuar Coast Shelf Sci 29: $1-10$

Hu X, Wei J, Song W (1999) Ecology of microzooplankton in the marine coastal waters (in Chinese). In: Song W (ed) Progress in protozoology. Qingdao Ocean University Press, Qingdao, p 297-324

Jeffrey SW, Humphrey GF (1975) New spectrophotometric equations for determining chlorophylls $a, b, c_{1}$ and $c_{2}$ in higher plants, algae and natural phytoplankton. Biochem Physiol Pflanz 167:191-198

Kamiyama T (1995) Change in the microzooplankton community during decay of a Heterosigma akashiwo bloom. J Oceanogr 51:279-287

Kamiyama T, Tsujino M (1996) Seasonal variation in the species composition of tintinnid ciliates in Hiroshima Bay, the Seto Inland Sea of Japan. J Plankton Res 18:2313-2327

Perez MT, Dolan JR, Fukai E (1997) Planktonic oligotrich ciliates in the NW Mediterranean: growth rates and consumption by copepods. Mar Ecol Prog Ser 135:89-101

Perez MT, Dolan JR, Vidussi F, Fukai E (2000) Diel vertical distribution of planktonic ciliates within the surface layer of the NW Mediterranean (May 1995). Deep-Sea Res I 47 : 479-503

Pierce RW, Turner JT (1994) Plankton studies in Buzzards Bay, Massachusetts, USA. IV. Tintinnids, 1987 to 1988. Mar Ecol Prog Ser 112:235-240

Putt M, Stoecker DK (1989) An experimentally determined carbon:volume ratio for marine 'oligotrichous' ciliates from estuarine and coastal waters. Limnol Oceanogr 34: 1097-1103

Sanders RW (1987) Tintinnids and other microzooplankton seasonal distributions and relationships to resources and hydrography in a Maine estuary. J Plankton Res 9:65-77

Strickland JDH, Parsons TR (1972) A practical handbook of seawater analysis. J Fish Res Board Can 167

Wasik A, Mikolajczyk E (1994) Annual cycle of tintinnids in Admiralty Bay with an emphasis on seasonal variability in Cymatocylis affinis/convallaria lorica morphology. J Plankton Res 16:1-8

Submitted: May 15, 2000; Accepted: October 12, 2000 Proofs received from author(s): November 15, 2000 